\title{
On analysis of operating efficiency of autonomous ventilation systems
}

\author{
Arman Kostuganov ${ }^{1 *}$, and Yuri Vytchikov ${ }^{1}$ \\ ${ }^{1}$ Samara State Technical University, Institute of Architecture and Civil Engineering, \\ 194, Molodogvardeyskaya St., 443001, Samara, Samara
}

\begin{abstract}
The paper deals with the causes and consequences of malfunctioning of natural and mechanical ventilation systems in civil buildings of Russia. Furthermore it gives their classification and analysis based on the literature review. On the basis of the analysis technical solutions for improving the efficiency of ventilation systems in civil buildings are summarized and the field of their application is specified. Among the offered technical solutions the use of autonomous ventilation systems with heat recovery is highlighted as one of the most promising and understudied. Besides it has a wide range of applications. The paper reviews and analyzes the main Russian and foreign designs of ventilation systems with heat recovery that are mostly used in practice. Three types of such systems: UVRK-50, Prana-150, TeFo are chosen for consideration. The sequence of field tests of selected autonomous ventilation systems have been carried out in order to determine the actual air exchange and efficiency of heat recovery. The paper presents the processed results of the research on the basis of which advantages and disadvantages of the tested ventilation systems are identified and recommendations for engineering and manufacturing of new design models of autonomous ventilation systems with heat recovery are formulated.
\end{abstract}

\section{Introduction}

Today, we can come across the term "sick building syndrome" not only in the specialized literature. Unfortunately, this is a widespread phenomenon in most civil buildings of Russia [1-6]. The main causes of the ventilation systems malfunctioning in premises of civil buildings are ambiguous and depend on lots of factors. The authors of this paper systematize the causes of the ventilation systems malfunctioning and classify them in table 1. Climatic causes arise in the case of using ventilation systems with gravity (natural) impulse of air movement. The papers [7-9] present quite reliable and detailed facts that for the largest and most densely-populated part of Russia the average insufficiency of the systems' natural ventilation is 5-6 months in a year. Regulatory causes - the papers [10 14] provide facts that as the requirements for thermal protection of buildings were reviewed, since 1995, the degree of air-tightness has been considerably increased. Codes of structural design were also changed, however, a number of factors affecting the estimated

\footnotetext{
*Corresponding author: kostuganow@mail.ru
} 
and actual values of the air exchange remain unconsidered as far as contemporary standards are concerned $[16,18,19]$.

Table 1. Classification of the causes of the ventilation systems malfunctioning in civil buildings.

\begin{tabular}{|l|l|}
\hline \multicolumn{1}{|c|}{ Type of causes } & \multicolumn{1}{c|}{ Causes' subject-matter } \\
\hline Climatic & $\begin{array}{l}\text { Insufficiency of year-round sustainable difference of gravitational } \\
\text { pressures of inside and outside air due to natural-climatic conditions }\end{array}$ \\
\hline Regulatory & $\begin{array}{l}\text { a) Strict requirements for thermal protection of building enclosing } \\
\text { structures, which result in their significant air-tightness } \\
\text { b) Regulations contain no clear procedural guidelines for ventilation } \\
\text { systems installation } \\
\text { c) There is no standardization of gas and ion air composition indicators } \\
\text { d) There are no data on the impact of numerous chemical air pollutants in } \\
\text { modern residential buildings on the human body } \\
\text { e) Standardization of air environment parameters is carried out on the } \\
\text { bases of the sanitary-hygienic principle, without taking into account the } \\
\text { complex physiological impact of the air environment on the human body }\end{array}$ \\
\hline Design & $\begin{array}{l}\text { Errors in the system design due to the lack of basic education, theoretical } \\
\text { knowledge and design experience, as well as the lack of clear procedural } \\
\text { guidelines for the design. }\end{array}$ \\
\hline Construction & $\begin{array}{l}\text { a) Poor quality of construction and installation works } \\
\text { b) Nonconformance of the completed construction, installation works to } \\
\text { the system design } \\
\text { c) Filling of ventilation shafts with construction waste }\end{array}$ \\
\hline Town-planning & $\begin{array}{l}\text { Planning the development of settlements without taking into account the } \\
\text { aerodynamic influence of air flows on buildings. }\end{array}$ \\
\hline Operating & $\begin{array}{l}\text { a) Replanning of premises including the reconstruction of ventilation ducts } \\
\text { b) Installation of air coolers for working indoors in the warm season } \\
\text { c) Installation of sealed windows and doors during the premises renovation } \\
\text { d) Connection of hoods' fans and axial ventilators' fans in bathrooms to } \\
\text { the communal exhaust ventilation system } \\
\text { e) Incorrect connection of fan motor phases }\end{array}$ \\
\hline
\end{tabular}

Design causes come up quite frequently in practice not only in Russia but also in foreign countries $[6,13,15]$. The same factors are mainly behind town-planning causes. Construction and installation causes are also wide-spread in practice due to lack of skilled workers, low level of work organization, deviations from the design. Operating causes are, perhaps, the most common for existing buildings both in Russia and foreign countries [13]. It is the result of technical illiteracy of premises' owners or specialists of management companies. Climatic, regulatory, design and town-planning causes can and should be eliminated at the stage of systems design by relevant research and design organizations.

Today one of the most common methods to ventilate civil buildings (especially residential buildings) is installation of the low-effective system of natural exhaust ventilation with unorganized air intake due to its relative cheapness and minimum operating costs. To eliminate existing defects in the system of natural exhaust ventilation, combined or hybrid ventilation is used. It includes elements of balanced natural and mechanical ventilation systems. One of the most promising and the least investigated methods of providing air exchange in premises of civil buildings is the installation of autonomous (decentralized) ventilation systems for separate rooms. This method has both advantages and disadvantages. The disadvantages include relatively high cost of systems' installation and operation, the occurrence of additional noise sources, some disruption of the interior space. On the other hand, the advantages include the possibility of organizing a sustainable air exchange in the room as well as the air heat recovery. If we take into consideration that 
according to various estimates the heat loss with air exchange in modern buildings can reach $25 \%$ of the total heat loss [17], the latter advantage becomes even more significant. It is also worth mentioning that this method of air exchange is applicable for all civil buildings regardless of their number of stories. Because of the mentioned above prospects, insufficient awareness and a wide range of applications for civil buildings, the authors of this work examine the effectiveness of using some models of autonomous ventilation systems according to the criteria of the created air exchange and the effectiveness of heat transmission defined in the course of field tests.

The purposes of this study are:

1. To determine the actual air exchange and the effectiveness of heat transmission in some models of autonomous ventilation systems in the course of field tests;

2. To compare the received values with the regulatory requirements;

3. To identify additional evaluation criteria for these systems on the basis of all data obtained during the tests;

4. To formulate recommendations for the design and manufacturing of new models of autonomous ventilation systems based on the results of the study.

\section{Materials and methods}

At present there are quite a lot of manufacturers of ventilation equipment who offer similar systems, for example, the models "UVRK", "Prana", "Tefo", "Reventa", "Aeroeco", "Meltem", "AirLaska", "Frivent" and others. Based on the criteria that these systems have various heat exchangers for heat recovery, they are adapted to the climatic conditions of Russia and represented in the Russian market of goods at affordable prices we have chosen the following systems for testing: UVRK-50 (manufacturer company - LLC Research and Production Company "Ekoterm", the city of Omsk, Russia), Prana-150 (manufacturer company - "Prana"; the city of Lvov, Ukraine), Tefo (manufacturer company - LLC "Teploobmen"; the city of Sevastopol, Russia). The selected system models are shown in figures $1-3$.

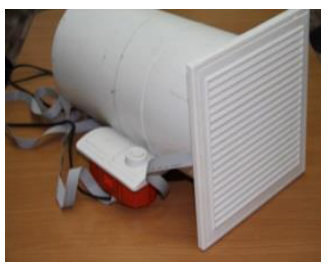

Fig. 1. UVRK-50. System.

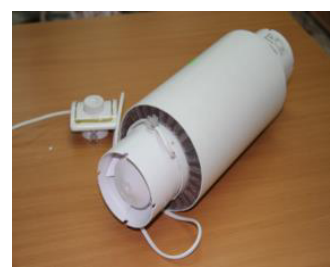

Fig. 2. Prana-150 system.

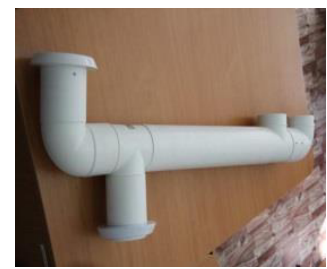

Fig. 3. Tefo system.

Field tests of the systems have been carried out by the authors of this research in the period of 2014 - 2016 in the laboratory of the Heat, Gas Supply, Ventilation and HydroMechanics Department of the Orenburg State University. For purposes of testing a hole was made in the outer wall of the laboratory with a diameter of $250 \mathrm{~mm}$ (figures 4-6), in which the tested system models were installed (figures 7-8).

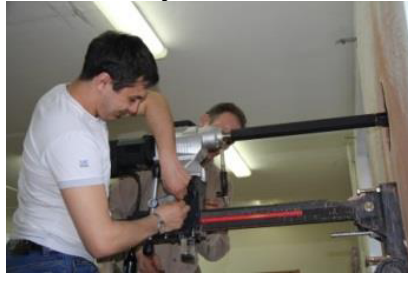

Fig. 4. Installing the equipment.

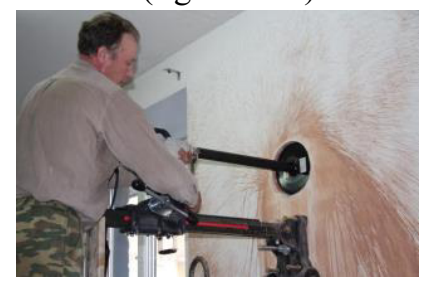

Fig. 5. Drilling a hole.

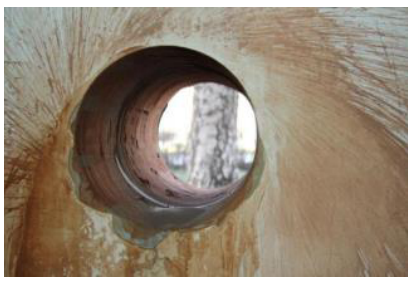

Fig. 6. Resulting hole. 


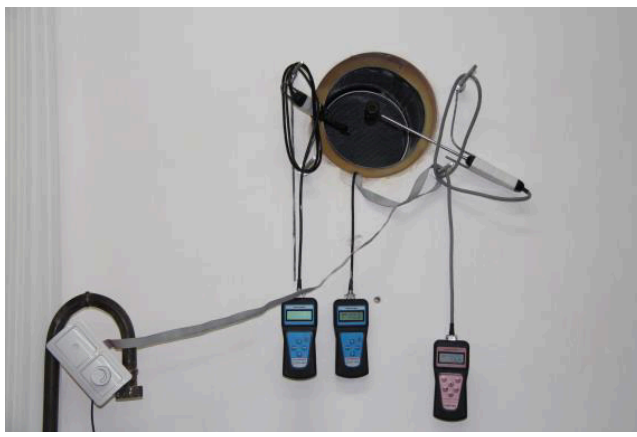

Fig. 7. UVRK-50 system (view from inside).

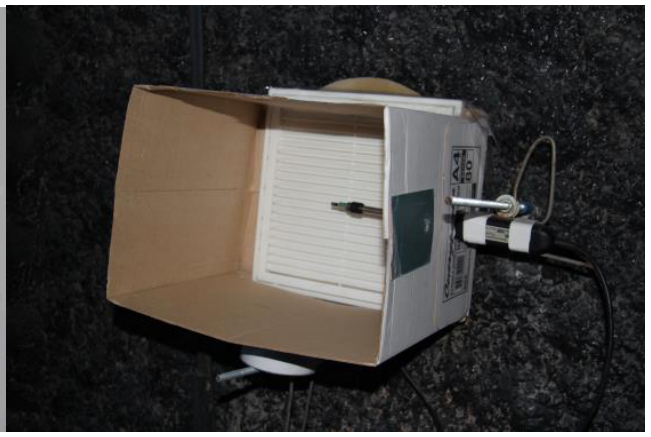

Fig. 8. UVRK-50 system (view from outside).

Thus, when conducting field tests all systems were installed in the hole made in the outer wall. The locations of measuring instruments are listed in table 2.

Table 2. The locations of measuring instruments for systems' field tests.

\begin{tabular}{|l|l|l|l|}
\hline Name of the system & $\begin{array}{l}\text { Name of the measuring } \\
\text { instrument }\end{array}$ & $\begin{array}{l}\text { Location of the } \\
\text { sensor }\end{array}$ & $\begin{array}{l}\text { Location of the } \\
\text { module }\end{array}$ \\
\hline \multirow{4}{*}{ "UVRK-50" } & Anemometer ISP MG-4 & Inside & Inside \\
\cline { 2 - 4 } & $\begin{array}{l}\text { Thermohygrometer THZ } \\
\text { MG-4.01 }\end{array}$ & Outside & Inside \\
\cline { 2 - 4 } & $\begin{array}{l}\text { Thermohygrometer THZ } \\
\text { MG-4.01 }\end{array}$ & Inside & Inside \\
\hline \multirow{5}{*}{ "Prana-150" } & Anemometer ISP MG-4 & Inside & Inside \\
\hline & Anemometer ISP MG-4 & Outside & Inside \\
\cline { 2 - 4 } & $\begin{array}{l}\text { Thermohygrometer THZ } \\
\text { MG-4.01 }\end{array}$ & Outside & Inside \\
\cline { 2 - 4 } & $\begin{array}{l}\text { Thermohygrometer THZ } \\
\text { MG-4.01 }\end{array}$ & Inside & Inside \\
\hline
\end{tabular}

Field tests of systems were carried out in winter 2014, 2015 when the average daily temperatures of outdoor air reached stable negative values of $6.1^{\circ} \mathrm{C}$ below zero (which is the average temperature during the heating period for the city of Orenburg). Test methods included recording of the results by operators who observed temperature, relative humidity, air flow rate during the system testing over the interval $3 \ldots .5$ seconds. The duration of experimental runs was $20 \ldots 25$ minutes. The beginning of the tests was preceded by the systems' trial run (at least for an hour) to start the operating mode close to the stationary mode. The tests were performed in the modes corresponding to average and maximum air flow rate formed at the outlets of the air distribution holes of the systems. The measurements were carried out in sections defined beforehand where the air parameters are stable and correspond to average values for both modes of testing. Tests with minimum capacity were not carried out, since during the prearranged experiments it was proved that air exchange in systems at this mode practically stops.

As a result of several field tests the test protocols were formed. Their data were used when calculating the values of actual air exchange and effectiveness of heat transmission in the tested models of autonomous ventilation systems. The actual air exchange values were calculated according to the formula:

$$
L=3600 \cdot F \cdot v_{s}
$$

$L$ - the actual volumetric air consumption, $\mathrm{m}^{3} / \mathrm{h} ; F$ - the cross-sectional area, in which the rate was measured, $\mathrm{m}^{2} ; v_{g}$ - the average value of air flow rate, $\mathrm{m} / \mathrm{s}$; 
The average value of air flow rate was calculated as the average value of the following mathematical estimates of the distribution of variables: the arithmetic average, the arithmetic average $90 \%$ of the sample, the median, the median amplitude, the amplitude center.

The efficiency of heat transmission in the heat exchanger - heat recovery unit was determined by the expression:

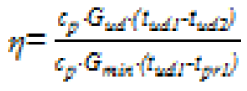

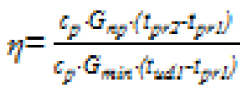

$\eta$ - the efficiency of heat transmission in the heat exchanger - heat recovery unit; $G_{u d}, G_{p r}$ mass consumption of intake and removed air respectively, $\mathrm{kg} / \mathrm{s} ; G_{\min }$ - the lower value of mass air consumption, $\mathrm{kg} / \mathrm{s} ; c_{p}$ - mass specific heat of air at constant pressure, $\mathrm{J} /\left(\mathrm{kg} \cdot{ }^{\circ} \mathrm{C}\right)$; $t_{p r}, t_{p r 2}$ - intake air temperature respectively at the inlet and at the outlet of the heat exchanger - heat recovery unit, ${ }^{\circ} \mathrm{C} ; t_{u d l}, t_{u d 2}$ - temperatures of the removed air at the inlet and at the outlet of the heat exchanger-heat recovery unit respectively, ${ }^{\circ} \mathrm{C}$;

The results of the conducted research are presented in the next section of this paper.

\section{Results}

In accordance with the purposes and objectives of the research the values of actual air exchange and efficiency of heat transmission in the tested system models were identified. The average intervals of the obtained results are presented in tables 3 and 4 .

Table 3. The results of calculating the actual values of air exchange and efficiency of heat transmission in the tested system models at average capacity mode.

\begin{tabular}{|c|c|c|c|c|c|c|c|}
\hline 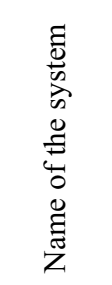 & 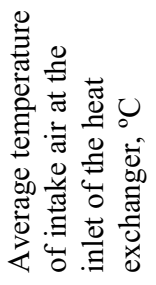 & 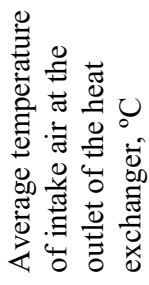 & 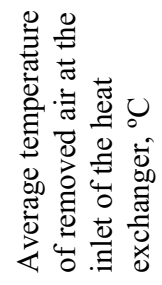 & 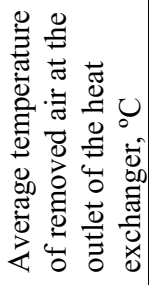 & 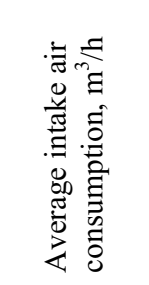 & 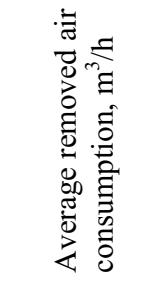 & 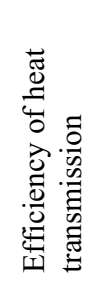 \\
\hline $\begin{array}{l}\text { UVRK- } \\
50\end{array}$ & $\begin{array}{lll}-1,0 & \ldots & - \\
13,0 & & \end{array}$ & $\begin{array}{l}+17,0 \\
+18,0\end{array}$ & $\begin{array}{l}+18,0 \\
+21,0\end{array}$ & $\begin{array}{l}0,0 \ldots \\
-12,0\end{array}$ & $30 \ldots 35$ & $30 \ldots 35$ & $\begin{array}{l}0,7 \\
0,8\end{array}$ \\
\hline TeFo & $\begin{array}{l}-25,0 \ldots \\
-25,5\end{array}$ & $\begin{array}{l}-4,9 \ldots \\
-10,7\end{array}$ & $\begin{array}{l}+23,7 \ldots \\
+26,4\end{array}$ & $\begin{array}{l}-23,7 \ldots \\
-24,3\end{array}$ & $\begin{array}{ll}11,4 & \ldots \\
12,2 & \end{array}$ & $18,5 \ldots 21,0$ & $\begin{array}{ll}0,3 & \ldots \\
0,4 & \end{array}$ \\
\hline $\begin{array}{l}\text { Prana } \\
150\end{array}$ & $\begin{array}{l}-17,9 \ldots \\
-21,7\end{array}$ & $\begin{array}{l}-6,9 \ldots \\
-9,7\end{array}$ & $\begin{array}{l}+15,9 \ldots \\
+16,4\end{array}$ & $\begin{array}{l}-4,6 \ldots \\
-14,7\end{array}$ & $\begin{array}{l}48,1 \\
\ldots 51,2\end{array}$ & $\begin{array}{l}18,2 \\
30,0\end{array}$ & $\begin{array}{ll}0,3 & \ldots \\
0,5 & \end{array}$ \\
\hline
\end{tabular}


Table 4. The results of calculating the actual values of air exchange and efficiency of heat transmission in the tested system models at maximum capacity mode.

\begin{tabular}{|c|c|c|c|c|c|c|c|}
\hline 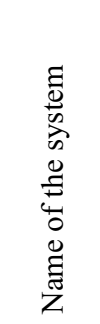 & 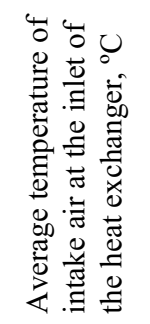 & 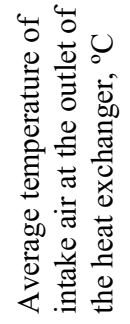 & 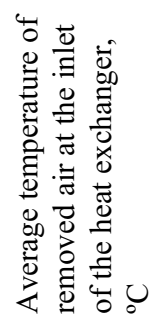 & 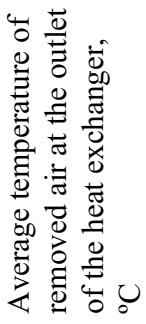 & 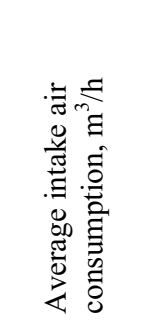 & 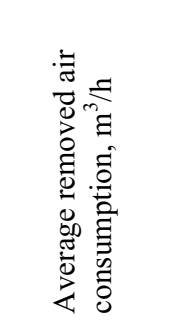 & 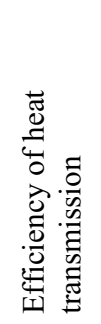 \\
\hline $\begin{array}{l}\text { UVRK } \\
-50\end{array}$ & $\begin{array}{lll}-1,0 & \ldots & - \\
13,0 & & \end{array}$ & $\begin{array}{l}+17,0 \ldots \\
+18,0\end{array}$ & $\begin{array}{l}+18,0 \\
+21,0\end{array}$ & $\begin{array}{l}0,0 \ldots \\
-12,0\end{array}$ & $50 \ldots 55$ & $50 \ldots 55$ & $\begin{array}{ll}0,7 & \ldots \\
0,8 & \end{array}$ \\
\hline TeFo & $\begin{array}{l}-26,0 \ldots \\
-26,2\end{array}$ & $\begin{array}{l}-2,0 \ldots \\
-3,6\end{array}$ & $+27,0$ & $\begin{array}{l}-21 \ldots \\
-22\end{array}$ & $\begin{array}{l}14,8 \\
33,3\end{array}$ & $\begin{array}{l}25,3 \\
27,0\end{array}$ & $\begin{array}{ll}0,4 & \ldots \\
0,5 & \end{array}$ \\
\hline $\begin{array}{l}\text { Prana } \\
150\end{array}$ & $\begin{array}{l}-19,8 \ldots \\
-20,8\end{array}$ & $\begin{array}{l}-5,2 \ldots . \\
-9,2\end{array}$ & $\begin{array}{l}+16,8 \ldots \\
+23,6\end{array}$ & $\begin{array}{l}-0,3 \ldots \\
-4,7\end{array}$ & $\begin{array}{l}24,7 \\
30,4\end{array}$ & $\begin{array}{l}28,2 \\
48,6\end{array}$ & $\begin{array}{ll}0,3 & \ldots \\
0,5 & \end{array}$ \\
\hline
\end{tabular}

When processing the test results the values of variables' measurement errors were also determined.

Table 5. Maximum absolute error values recorded by measuring instruments, when determining the values of air rate and temperature

\begin{tabular}{|l|l|l|l|}
\hline Name of the system & Name of the instrument & Measured parameter & $\begin{array}{l}\text { Value of absolute } \\
\text { error }\end{array}$ \\
\hline \multirow{3}{*}{ UVRK-50 } & ISP 4 MG & Air temperature & $\pm 0,5^{\circ} \mathrm{C}$ \\
\cline { 2 - 4 } & & Air rate & $\pm 0,2 \ldots 0,3 \mathrm{~m} / \mathrm{c} \mathrm{m} / \mathrm{s}$ \\
\cline { 2 - 4 } & THZ MG 4.01 & Air temperature & $\pm 0,5^{\circ} \mathrm{C}$ \\
\hline \multirow{2}{*}{ Prana-150 } & ISP 4 MG & Air temperature & $\pm 0,5^{\circ} \mathrm{C}$ \\
\cline { 2 - 4 } & & Air rate & $\pm 0,15 \ldots 0,3 \mathrm{~m} / \mathrm{c} \mathrm{m} / \mathrm{s}$ \\
\cline { 2 - 4 } & THZ MG 4.01 & Air temperature & $\pm 0,5^{\circ} \mathrm{C}$ \\
\hline \multirow{2}{*}{ TeFo } & ISP 4 MG & Air temperature & $\pm 0,5^{\circ} \mathrm{C}$ \\
\cline { 2 - 4 } & & Air rate & $\pm 0,15 \ldots 0,3 \mathrm{~m} / \mathrm{c} \mathrm{m} / \mathrm{s}$ \\
\cline { 2 - 4 } & THZ MG 4.01 & Air temperature & $\pm 0,5^{\circ} \mathrm{C}$ \\
\hline
\end{tabular}

As table 5 shows the temperature measurements were carried out with the maximum indicated error not exceeding the value of $\pm 0,5^{\circ} \mathrm{C}$. That does not exceed $10 \%$ of the relative measurement error. It should be noted that when calculating the rate measurement errors for the ISP MG4 instruments the errors reach maximum values (from 5\% ... to $20 \%$ ). That is why the control measurement of rate was carried out with the multi-function instrument Testo 480. In general, the maximum value of the final results' relative error does not exceed $15 \%$.

The tables above show that the temperature values at the air inlet to the room for some system models are quite low (from $-2.0^{\circ} \mathrm{C}$ and to $-10.7^{\circ} \mathrm{C}$ ). That will create thermal discomfort during continuous operation of the system. The average of actual air consumption is also less than the standard values and the values declared by the manufacturers of systems. If we take the interval of minimum standard values of the intake air consumption per one person from 20 to $60 \mathrm{~m}^{3} / \mathrm{h}$, as it is clear from tables 4 and 5 , some tested system fall within this interval only at maximum capacity mode.

It should be mentioned that when preforming tests the fluctuation of room air temperature ranged from $0.5^{\circ} \mathrm{C}$ to $3{ }^{\circ} \mathrm{C}$, fluctuations in relative humidity ranged from $5 \%$ 
to $15 \%$, air mobility varied from $0.12 \mathrm{~m} / \mathrm{s}$ to $0.35 \mathrm{~m} / \mathrm{s}$, and noise level was from $38.6 \mathrm{dBA}$ to $50.1 \mathrm{dBA}$.

\section{Discussion}

As the result of the analysis of indicators' values obtained during the study, we can formulate the following recommendations for design and manufacture of new models of such systems:

1 In the design of new system models as the driving force of air movement the centrifugal fan must be used not the axial one. It is this particular design feature of the system, according to the authors, that causes low values of the actual air exchange and the efficiency of heat transmission of the tested models.

2 New system models must optimally combine two characteristics - the surface area of heat exchange should be as large as possible while the wall surface in the room should be as small as possible.

3 The design of system heat exchanger must be easily manufactured and effective when cleaning the surface of heat exchanger (the example of heat exchanger system design "TeFo").

4. The design of new system models must include filters for cleaning of the air coming from the street and the air removed from the premises.

5. To reduce noise levels up to standard values the installation of fans should be made outside, or as far as possible from the room air outlet.

6 New models of systems must be suitable for repairing to the maximum extent.

7 System user control should be as simple as possible.

8 The warranty period of new system models should be within minimum one year.

9 For easy installation the degree of readiness of new system models should be maximized.

It should be mentioned that around the same time the Kazan State University of Architecture and Civil Engineering was conducting similar field tests of some other types of devices for organizing the outside air intake including UVRK-50 [20]. In many aspects the similar results were obtained.

\section{Conclusions}

As a result of the conducted research the main quantitative parameters that must be met in new models of autonomous ventilation systems have been set. These include:

1 Guaranteed air exchange at the level of sanitary norms (minimum $30 \mathrm{~m}^{3} /$ hour).

2 Share of heat return from $50 \%$ to $75 \%$ depending on the mode of equipment operation, as well as the external and internal environment;

3 Energy consumption at the level of modern household appliances;

4 Compactness - the system should fit in the average size window;

5 The systems shall be available to users for maintenance and minor repairs.

Based on the results of the research and considering the above recommendations a new model of autonomous ventilation systems for wall mounting was developed at the premises of LLC " SPE "Pneumax". As part of further research of this topic it is planned to carry out tests (field and in climatic chamber) of the model of autonomous ventilation systems, as well as to develop a type of such system with heat recovery suitable for installation under the window sill. 


\section{Acknowledgement}

The authors express their deep gratitude for providing invaluable assistance in conducting the study to Candidate of Technical Sciences, Professor, Head of the Department "Heat and Gas Supply and Ventilation" at the Novosibirsk State University of Architecture and Civil Engineering (Sibstrin) Rustam Shamilyevich Mansurov.

The authors also express their gratitude to the Foundation for Assistance to Small Innovative Enterprises in Science and Technology for the support and grant-making to conduct further research on the topic within a framework of the all-Russia innovation competition "U. M. N. I. K.".

\section{References}

1. O. Fanger, AVOK 2, 12-19 (2006)

2. Yu.A. Tabunshchikov, AVOK 5, 4-11 (2008)

3. Yu.A. Tabunshchikov, AVOK 4, 4-7 (2007)

4. A.B. Kostuganov, Yu.S. Vytchikov, Traditions and innovations in construction and architecture. Building technologies. Collection of articles, 309-313 (Samara State University of Architecture and Civil Engineering, 2016)

5. B.M. Romeyko, D.V. Zelentsov, Traditions and innovations in construction and architecture. Building technologies. Collection of articles, 783-784 (Samara State University of Architecture and Civil Engineering, 2014)

6. N.P. Tyurin, E.P. Lapin, G.I. Titov, Yu.E. Zakharova, Traditions and innovations in construction and architecture. Building technologies. Collection of articles, 267-271 (Samara State University of Architecture and Civil Engineering, 2013)

7. M.V. Bodrov, V.Yu. Kuzin, M.S. Morozov, S. O. K. 1, 74-77 (2016)

8. M.V. Bodrov, V.Yu. Kuzin, D.Yu. Kuzin, Privolzhsky scientific journal 4, 26-32 (2016)

9. M.V. Bodrov, V.P. Boldin, V.Yu. Kuzin, M.N. Kucherenko, Privolzhsky scientific journal 1, 54-59 (2015)

10. Yu.S. Vytchikov, A.V. Sidorova, Traditions and innovations in construction and architecture. Building technologies. Collection of articles, 284-286 (Samara State University of Architecture and Civil Engineering, 2013)

11. Yu.S. Vytchikov, A.V. Sidorova, Urban Construction and Architecture 4, 87-94 (2013) DOI 10.17673/Vestnik.2013.04.15

12. V.I. Vesnin, Urban Construction and Architecture 3, 10-16 (2016) DOI 10.17673/Vestnik.2016.03.2

13. R. Schulte, B. Bridges, D. Grimsrud, AVOK 8, 36-47 (2005)

14. A.M. Saifutdinova, V.N. Kupriyanov, Proceedings of the Kazan State University of Architecture and Civil Engineering 1, 113-118 (2014)

15. N.P. Tyurin, E.P. Lapin, Traditions and innovations in construction and architecture. Proceedings of the 70th anniversary all-Russian scientific and technical conference. Samara State University of Architecture and Civil Engineering, pp. 265-266 (2013)

16. A.G. Rymarov, S. O. K. 11, 75-77 (2012)

17. V.G. Gagarin, V.V. Kozlov, Vestnik MGSU 7, 59-66 (2011)

18 A.G. Rymarov, V.V. Savichev, News of higher educational institutions. Civil Engineering 4, p. 99-102 (2014) 
19. V.N. Kupriyanov, A.M. Saifutdinova, Proceedings of the Kazan State University of Architecture and Civil Engineering 1, 109-119 (2013)

20. V.N. Kupriyanov, A.M. Saifutdinova, A.M. Ziganshin, I.Sh. Safin, Bulletin of the Volga regional branch of the Russian Academy of architecture and construction sciences 16, 245-254 (2013) 